\title{
LÄÄKÄRIN JA POLIITIKON VIESTINTÄOSAAMISEN JÄLJILLÄ
}

\author{
Jonna Mönkkönen \& Minna Finstad
}

\section{TIIVISTELMÄ}

Tässä artikkelissa pureudutaan lääkärin ja poliitikon viestintäosaamiseen. Tavoitteenamme on pohtia, millaisia merkityksiä ja jäsennyksiä viestintä-ja vuorovaikutusosaamisen käsitteet saavat tai voisivat saada lääkärin ammatissa sekä osana poliitikon tehtävää. Kun viestintäosaamista tarkastellaan ammatin tai tehtävän näkökulmasta, voidaan ajatella, että viestintäosaaminen limittyy yksilön ammattiosaamiseen. Kostiainen $(2003,10)$ on määritellyt viestintäosaamisen seuraavasti: "Viestintäosaaminen tarkoittaa yksilön viestinnällistä toimintakykyä eli niitä ihmisten väliseen vuorovaikutukseen liittyviä tietoja, taitoja, kykyjä, ominaisuuksia, asennoitumista ja ymmärrystä, joita ammattilainen tarvitsee työssä menestyäkseen ja joille hän antaa omat merkityksensä ja oman painoarvonsa. "Tavoitteemme on pohtia, mitä annettavaa puheviestinnällisellä lähestymistavalla voisi olla poliitikkojen viestintäosaamisen tarkastelulle ja millaisena viestintään ja vuorovaikutukseen liittyvä osaaminen lääkörin työssä näyttäytyy.

Asiasanat: viestintäosaaminen, vuorovaikutusosaaminen, lääkäripotilas-viestintä, poliitikon viestintä

\section{JOHDANTO}

Modernissa tietoyhteiskunnassa yhä useampi työ edellyttää viestintää ja tapahtuu vuorovaikutuksessa muiden ihmisten kanssa. Etenkin niin sanotuissa ihmissuhdeammateissa työn onnistuminen riippuu eritoten ihmisten välisen vuorovaikutuksen toimivuudesta (Gerlander \& Takala 2000, 157). On selvää, että viestintäosaamisen 
merkitys tulee yhä tärkeämmäksi tarkasteltaessa yksilön ammattiosaamista tai kykyä suoriutua työstään tuloksellisella tavalla. Viestintäosaaminen on ollut puheviestinnän alalla erityisen kiinnostuksen kohteena viime vuosina.

Tarkastelemme viestintäosaamista lääkärin ammatissa sekä osana poliitikon tehtävää. Lääkäri ja poliitikko toimivat kumpikin tehtävissä, joissa viestinnällä ja vuorovaikutuksella on keskeinen rooli. Viittaamme lääkärin tehtävänkuvaan sanalla ammatti, sillä kyseessä on perinteinen yhteiskunnallinen professio (ks. esim. Antikainen 1998; Freidson 1994). Poliitikon tehtävä ei ole rinnastettavissa perinteiseen professioon vaan on luonteeltaan laaja-alaisempi yhteiskunnallinen edustus- ja luottamustehtävä. Tämän takia poliitikkojen työstä puhuessamme käytämme sanaa tehtävä. Viestintäosaaminen - ja erityisesti sen puute - kummankin ammatin tai tehtävän kohdalla on herättänyt paljon keskustelua julkisuudessa. Poliitikkojen viestintää ja julkista esiintymistä on kritisoitu koko edustuksellisen järjestelmän alkuajoista lähtien (Lappalainen 2006, 259). Viime aikoina myös lääkärien viestintään ja vuorovaikutustaitoihin on alettu kiinnittää yhä enemmän huomiota. Pitkään katsottiin, että lääkärin vuorovaikutustaidot kehittyvät kliinisten taitojen karttumisen ohessa ja seuraamalla vanhempien kollegoiden toimintaa potilaiden kanssa. Tilanne muuttui 1990 -luvulla, ja vuorovaikutusopinnot vakiintuivat osaksi lääkäreiden peruskoulutusta sekä Suomessa että ulkomailla (Makoul 2003; Pyörälä 2001).

Lääkärin ja poliitikon tehtävänkuvat ovat monessa suhteessa hyvin erilaiset. Lääkärin ammattia voidaan hyvällä syyllä pitää ihmissuhdeammattina, jossa lääkärin ja potilaan välisellä viestinnällä on usein selkeät tavoitteet, joita vuorovaikutuksessa pyritään toteuttamaan. Myös poliitikkona toimiminen on etupäässä viestintää niin yksilöiden, ryhmittymien kuin koko yhteiskunnan kanssa. Silti poliitikon tehtävästä ei välttämättä voida erottaa yhtä selkeää vuorovaikutussuhdetta tai asettaa yhtä tarkkarajaisia tavoitteita viestinnälle. Uskomme, että juuri tämänkaltaiset erot tehtävien luonteissa tarjoavat hedelmällisen lähtökohdan aihepiirin tarkastelulle viestintäosaamisen näkökulmasta. 
Tavoitteenamme on pohtia, millaisia merkityksiä ja jäsennyksiä viestintäosaamisen käsite saa tai voisi saada lääkärin ammatissa sekä osana poliitikon tehtävää. Millaista viestintäosaamista poliitikko tai lääkäri työssään tarvitsee? Millaisissa asioissa ja tilanteissa näiden kahden työn näkökulmat viestintäosaamiseen ovat yhteneväisiä ja missä ne eroavat toisistaan?

Tämänkaltaisen teoreettisen pohdiskelun uskomme tarjoavan hedelmällisen lähtökohdan ymmärtää eri ammateissa vaadittavaa viestintäosaamista. Lisäksi uskomme sen antavan yleisemminkin lähtökohtia viestintäosaamisen käsitteen yhä monipuolisemmalle teoreettiselle tulkinnalle ja hahmottamiselle.

\section{VIESTINTÄOSAAMINEN PUHEVIESTINTÄTIETEESSÄ}

Viestintäkompetenssin eli -osaamisen tutkimushistoria on monitieteistä. Varhaisimmat systemaattiset pyrkimykset määritellä viestintäkompetenssia löytyvät jo antiikin sofisteilta ja Aristoteleen Retoriikasta (Rubin 1990, Valkosen 2003, 25 mukaan). Myös puheviestintätieteessä, kielitieteissä, käyttäytymistieteissä, psykologiassa, sosiaalipsykologiassa, mediatutkimuksessa, tiedotusopissa, yhteiskuntatieteissä ja filosofiassa on tarkasteltu ja määritelty viestintäosaamista eri näkökulmista (Valkonen 2003, 27). Puheviestintätieteessä viestintäkompetenssin käsitettä on mallinnettu muun muassa kognitiivisesta, affektiivisesta ja taitokeskeisestä näkökulmasta (Spitzberg \& Cupach 1984). Koska viestintäkompetenssia on tutkittu useista eri lähtökohdista, on tutkimusalue sinällään hyvin moniulotteinen (Valkonen 2003, 26).

Puheviestintätieteessä viestintäkompetenssiin on monesti liitetty 1) viestintään liittyvät tiedot ja kognitiiviset yksilötekijät, 2) viestintätaidot, 3) viestintämotivaatio ja viestintään liittyvät käsitykset ja taipumukset sekä tehokkuuden ja tarkoituksenmukaisuuden näkökulma, jolloin tarkoituksenmukainen viestintä tarkoittaa sosiaalisten ja interpersonaalisten normien, sääntöjen ja odotusten 
mukaista käyttäytymistä ja tehokas viestintä sellaista viestintäkäyttäytymistä, jolla saavutetaan viestinnälle asetetut tavoitteet (Rubin 1990, Valkosen 2003, 26 mukaan). Viestintäosaaminen merkitsee myös kykyä tilanneherkkyyteen ja joustavuuteen erilaisissa viestintätilanteissa (Parks 1994, 595). Teoreettisena käsitteenä viestintäosaaminen on suhteellisen monitulkintainen. Erityisen ongelmallista käsitteen määrittelyssä on ollut kompetenssin osatekijöiden välisten suhteiden selvittäminen sekä kompetenssin tilannekohtaisuuden ja piirretyyppisyyden huomioiminen (Valkonen 2003, 35). Myös lähi- ja rinnakkaiskäsitteiden käyttö tuo oman haasteensa käsitteiden määrittelyyn.

Viestintäkompetenssia ja viestintätaitoa käytetään välillä toistensa synonyymeina, vaikka kompetenssin käsite nähdään taidon käsitettä laajempana (Valkonen 2003, 25). Viestintäkompetenssia jäsennetään monesti erilaisten taitoluokitusten avulla. Viestintäkompetenssia on havainnollistettu esimerkiksi luettelemalla tietyn ammatin kannalta keskeisiä taitoja (Kostiainen 2003, 31). Valon $(1995,70)$ mukaan puheviestinnän opetuksessa taitoluetteloita on usein esitetty oppimistavoitteiden havainnollistamiseksi. Työelämän viestinnällisiä vaatimuksia kuvattaessa taitojaottelut saattavat kuitenkin jäädä erillisiksi ammattitaidon päälle liimattaviksi vaatimuslistoiksi (Kostiainen 2003, 31). Sen vuoksi olisi perusteltua tarkastella viestintäosaamista laajemmin kuin pelkästään taitonäkökulmasta.

Puheviestintätieteellisessä kirjallisuudessa käytetään käsitteitä viestintäkompetenssi, puheviestintäkompetenssi, viestintäosaaminen ja puheviestintäosaaminen (ks. esim. Valkonen 2003; Kostiainen 2003; Valo 1995). Näihin osaamisen ulottuvuuksien kuvauksiin on useimmiten liitetty yksilön viestintään ja vuorovaikutukseen liittyvät tiedot, taidot ja motivaatio sekä tehokkuuden ja tarkoituksenmukaisuuden periaatteet. Kostiainen $(2003,10)$ on määritellyt viestintäosaamisen tarkoittavan "yksilön viestinnällistä toimintakykyä, jonka avulla yksilö toimii ammatissaan: niitä ihmisten väliseen vuorovaikutukseen liittyviä tietoja, taitoja, kykyjä, omi- 
naisuuksia, asennoitumista ja ymmärrystä, joita ammattilainen tarvitsee työssä menestyäkseen ja joille hän antaa omat merkityksensä ja oman painoarvonsa." Valkonen (2003, 35-39) liittää puheviestintäkompetenssiin yksilön kognitiiviset rakenteet, viestinnän tiedot ja metakognitiiviset taidot, affektiivisen ulottuvuuden, puheviestintätaidot sekä viestinnän eettiset periaatteet. Valo $(1995,69)$ tiivistää aikaisempaa kompetenssitutkimusta ja kirjoittaa, että puheviestintätaidot on totuttu kytkemään osaksi puheviestintäkompetenssia, joihin kuuluu viestintämotivaatio ja viestintään liittyvät taipumukset, viestintätieto ja kognitiiviset yksilötekijät sekä viestintätaidot tai -suoritukset. Puheviestintäkompetenssin lähi- tai rinnakkaiskäsitteenä voidaan joskus käyttää käsitettä interpersonaalinen kompetenssi (Valkonen 2003, 33). Interpersonaalisen kompetenssin rinnalla voidaan käyttää käsitettä relationaalinen kompetenssi, jolla voidaan tarkoittaa sekä tehokkaiden ja tarkoituksenmukaisten viestintätaitojen että viestintäkäyttäytymisen tulosten tarkastelua erityisesti vuorovaikutussuhteen tasolla tai taitoa luoda ja ylläpitää vuorovaikutussuhteita (Valkonen 2003, 34). Myös lääkärin että poliitikon tehtävään liittyvää viestintäosaamista on mahdollista tarkastella relationaalisesta, suhteiden luomista ja ylläpitämistä koskevasta näkökulmasta, jossa viestintäosaamista tarkastellaan osana kahden ihmisen välistä suhdetta. Taitavuus viestinnässä liittyy tällöin viestintäsuhteeseen, kehittyy viestintäosapuolten yhteistyönä ja määrittyy viestintäosapuolten näkökulmasta (Spitzberg \& Cupach 1984, 67-70). Tämänkaltaista osaamista kuvaisi mielestämme osuvasti vuorovaikutusosaamisen käsite, jonka pohdintaan palaamme artikkelin lopussa.

Tässä artikkelissa tarkastelemme viestintäosaamista lääkärin ja poliitikon tehtävien näkökulmasta. Kun viestintäosaamista tarkastellaan ammatin tai tehtävän näkökulmasta, voidaan ajatella, että viestintäosaaminen limittyy yksilön ammattiosaamiseen (Kostiainen 2003). Näkökulmamme viestintäosaamiseen on puheviestintätieteellinen, vuorovaikutusta ja ihmissuhteiden luomista korostavasta näkökulma, jolloin rajaamme käsittelyn ulkopuolelle lukemiseen, kirjoittamiseen ja medialukutaitoon liitettävän viestintäosaamisen (ks. Valkonen 2003, 25). 
Viestintäosaamisen tutkimuksessa ei tällä hetkellä ole niinkään olennaista määritellä uusia taitoja kuin pohtia viestintäosaamisen uusia käyttöyhteyksiä sekä pyrkiä antamaan viestinnälle uusia merkityksiä ja jäsennyksiä erilaisissa työtehtävissä (Kostiainen 2003). Tämä kehotus toimii hyvänä lähtökohtana pohtia viestintäosaamista lääkärin ja poliitikon tehtävissä myös taitoulottuvuutta laajemmin. On tärkeää kiinnittää huomiota siihen, miten viestintäosaamisen käsite ylipäänsä sopii näiden luonteeltaan hyvin erilaisten työtehtävien tutkimukseen ja mitä annettavaa - niin teoreettisella kuin käytännöllisellä tasolla - käsitteellä kummassakin kontekstissa voi olla. Miten viestintäosaamisen käsite voi auttaa ymmärtämään paremmin näissä tehtävissä vaadittavia osaamisalueita tai antaa meille tietoa siitä, mitkä ovat viestinnän ja vuorovaikutuksen funktioita tai päämääriä kummassakin kontekstissa?

Seuraavaksi tarkastelemme kumpaakin kontekstia ensin erikseen ja pyrimme tätä kautta nostamaan esille niiden ydinilmiötä ja kysymyksiä. Tämän jälkeen tarkoituksena on luoda synteesiä, jossa vertailun sekä erojen ja yhtäläisyyksien analyysin avulla pyritään kohti kokonaisvaltaista teoreettista näkemystä siitä, millaisena viestintäosaaminen näiden kontekstien kautta hahmotettuna näyttäytyy sekä mitä uutta voimme oppia sen luonteesta käsitteellistämällä sitä kahdessa hyvin erityyppisessä kontekstissa.

\section{NÄKÖKULMIA LÄÄKÄRIN VIESTINTÄOSAAMISEEN}

\section{Lääkärin ammatin vuorovaikutuksellinen luonne}

Lääkärin ammatti on professio, johon kouluttaudutaan Suomessa yliopistoissa (Vainiomäki 1995, 39). Ensimmäinen asetus lääkärien laillistamisesta annettiin Suomessa 1800-luvun lopulla (Pesonen 1980, 365-369). Lääkärin ammattia voitaisiin luonnehtia ammatiksi, jossa työ tapahtuu keskeisesti vuorovaikutuksessa. Tällaisissa ammateissa ihmissuhdeulottuvuus on syvä, ja sen vuoksi niitä voidaan kutsua ihmissuhdeammateiksi tai interpersonaalisiksi 
ammateiksi (Gerlander \& Takala 2000, 157). Vainiomäki (1995, 23) korostaa, että "Lääkärin onkin ammatillisten tietojensa lisäksi kyettävä edesauttamaan sellaisen vuorovaikutustilanteen syntymistä, joka edistää potilaan ongelman selkiytymistä tai vaivan korjaantumista. Perusterveydenhuollossa lääkäriltä edellytetään tietojen ja taitojen lisäksi erityisen hyviä vuorovaikutustaitoja sekä potilastyössä että työyhteisössä ja väestön parissa."

Ihmissuhdeammateissa tarvitaan sekä oman erityisalan tietoja ja taitoja että vuorovaikutustaitoja ja ihmisen toimintaan liittyvää ymmärrystä (Rauste-von Wright \& von Wright 1994, 168). Lääkärin työssä tämä tarkoittaa, että lääkärin on oltava lääketieteen asiantuntija, mutta pelkkä substanssitieto ei riitä, ellei lääkärillä ole halua tai kykyä käyttää sitä jokaisessa vastaanottotilanteessa (Gerlander \& Takala 2000, 158). Lääketieteellinen osaaminen ja vuorovaikutukseen liittyvä osaaminen eivät siis sulje toisiaan pois, vaan ne liittyvät toisiinsa.

Lääkärin ammatissa viestintään liittyvä osaaminen kytkeytyy siihen kontekstiin, jossa lääkäri työtään tekee. Lääkärin työtehtävät voivat vaihdella paljonkin työpaikasta ja työnkuvasta riippuen. Lääkärit työskentelevät Suomessa sairaaloissa, terveyskeskuksissa, työterveyshuollossa, yksityisvastaanotoilla, opetus- ja tutkimustehtävissä sekä muissa tehtävissä, kuten hallintotehtävissä sekä järjestöjen ja lääketeollisuuden palveluksessa (Lääkärikysely 2006). Lääkärin viestintäosaamista voitaisiin tarkastella erikseen eri työskentelysektorien näkökulmasta tai esimerkiksi hoitotilanteissa eri-ikäisten potilaiden tai perheenjäsenten kanssa, tiimeissä muiden hoitohenkilökunnan jäsenten kanssa, erityistilanteissa kuten huonojen uutisten kertomisen yhteydessä tai vaikkapa viestintätekniikan käyttöön liittyen (Makoul 2003). Tässä artikkelissa rajaamme lääkärin viestintäosaamisen tarkastelun lääkärin ja potilaan väliseen viestintäsuhteeseen. Potilaan haastatteleminen on lääkärin työssä yksi keskeinen vuorovaikutustilanne, jonka onnistumisessa vuorovaikutukseen liittyvä osaaminen on olennaista (Cegala, McGee \& McNeilis 1996; Smith \& Hoppe 1991). Koska tarkaste- 
lun kohteeksi nousee nimenomaan tietty vuorovaikutustilanne ja vuorovaikutussuhde, painottuu tarkastelussa viestintäosaamisen relationaalinen näkökulma. Taitavuus viestinnässä liittyy tällöin viestintäsuhteeseen, kehittyy viestintäosapuolten yhteistyönä ja määrittyy viestintäosapuolten näkökulmasta (Spitzberg \& Cupach 1984, 67-70).

\section{Miten jäsentää lääkärin viestintäosaamista?}

Lääkärin ja potilaan välistä vuorovaikutusta on tutkittu runsaasti viimeisten 25 vuoden aikana (Thompson 2003). Lääkärin ja potilaan välisen vuorovaikutuksen toimivuus ratkaisee pitkälti sen, saako potilas vaivaansa oikean lääketieteellisen vastauksen. Lääkärin vastaanoton tuloksellisuutta osoittaa se, kuinka tyytyväisiä potilaat ovat, kuinka hyvin potilaat ymmärtävät lääkärin kertomia asioita, miten potilaat noudattavat lääkäriltä saamiaan ohjeita ja missä määrin potilaiden fyysiset oireet mahdollisesti vähenevät (Peräkylä, Eskola \& Sorjonen 2001, 11). Useissa tutkimuksissa on osoitettu, että lääkärin ja potilaan välinen vuorovaikutus on yhteydessä potilaan kokemaan hoitotyytyväisyyteen, ongelman ymmärtämiseen, diagnoosiin, lääketieteellisen tiedon ymmärtämiseen ja muistamiseen, hoito-ohjeiden noudattamiseen, hoitokanteisiin, elämänlaatuun ja hoitotuloksiin sekä lukuisiin psykologis-medikaalisiin muuttujiin kuten kipuun, jännittyneisyyteen, sydämen sykkeeseen ja verenpaineeseen (Brown, Steward \& Ryan 2003; Makoul 2003; Ong ym. 1995; Williams, Weinman \& Dale 1998). Vuorovaikutuksella ja sen onnistumisella on siis suuri merkitys lääkäri-potilassuhteessa.

Terveysviestinnän tutkimuksissa läk̈käri-potilasviestintää on usein tarkasteltu interpersonaalisena viestintänä ja suhteena (Gerlander 2003, 21). Gerlanderin $(2003,12)$ mukaan perinteisesti lääkärin ja potilaan välistä suhdetta on kuvattu paternalistisena: lääkäri ohjaa hoitoa ja tekee päätökset potilaan hoidosta. Hänen mukaansa kahden viimeisen vuosikymmenen aikana on siirrytty kohti näkemystä, jossa korostuu potilaan osallistuminen ja yhtei- 
nen päätöksenteko, ja vaikka lääkäri-potilassuhteet näyttäytyvät tasavertaisempina kuin aikaisemmin, eivät traditionaaliset vuorovaikutusasetelmat ole kadonneet. Lääkärin ja potilaan välinen viestintäsuhde ei perustu henkilökohtaiseen välittämiseen ja kiintymykseen, mutta tunteet kietoutuvat hoitoprosessiin, sillä potilas on usein huolissaan omasta terveydentilastaan, jolloin lääkäri voi kokea, että häneltä odotetaan välittämistä ja sen osoittamista vuorovaikutuksessa (Gerlander 2003, 36). Gerlanderin (2003, 36) mukaan Bridge ja Baxter (1992) puhuvat sekasuhteista (blended relationships), joissa ylittyvät ja sekoittuvat sekä ammattiin ja asemaan että henkilökohtaisuuteen pohjautuvien suhteiden elementit. Heidän mukaansa tällaisia ovat juuri ihmissuhdeammattilaisten ja asiakkaiden väliset suhteet, joissa on mukana sekä tehtävän suorittaminen ja taloudellinen palkinto että toisesta välittäminen ja kunnioittaminen. Lääkäri-potilassuhteen yksiselitteinen kuvaaminen onkin vaikeaa, sillä suhde on hyvin moni-ilmeinen (Gerlander 2003, 38). Perinteistä valta-asetelmaa lääkäri-potilassuhteessa lienee vaikea täysin unohtaa. Vaikka potilaiden tietoisuus ja aktiivisuus omasta hoidosta on lisääntynyt, ei potilailla kuitenkaan ole riittävästi tietoa diagnostisten päätelmien tekoon ilman lääkärin koulutusta (Ruusuvuori, Raevaara \& Peräkylä 2003).

Potilaan haastatteleminen tapahtuu useimmiten lääkärin vastaanotolla, eikä kahta täysin samanlaista vastaanottoa ole olemassa. Jokaisella potilaalla on oma tapansa viestiä, johon vaikuttaa vielä hänen senhetkinen sairautensa tai ongelmansa, ja yhtä lailla jokainen lääkäri on erilainen ja hänen persoonallisuutensa vaikuttaa siihen, kuinka hän lääketiedettä soveltaa (Peräkylä, Eskola \& Sorjonen 2001, 9). Peräkylän, Eskolan ja Sorjosen $(2001,12)$ mukaan Byrne ja Long (1976) olivat ensimmäisiä vuorovaikutustutkijoita, jotka kiinnittivät huomiota vastaanoton vaiheisiin. Heidän mukaansa vastaanoton vaiheita ovat aloitus, käynnin syyn selvittäminen, sanallinen ja/tai fyysinen tutkimus, potilaan tilanteen pohdinta eli diagnoosin tekeminen, hoidosta ja muista jatkotoimista keskusteleminen sekä vastaanoton lopetus. Vuorovaikutustaitojen opettamisen yhteydessä Kurtz, Silverman ja Draper $(2005,41)$ 
kuvaavat potilashaastattelun etenemistä myös vaiheittain, mutta siten, että vuorovaikutuksen rakenne ja suhteen luominen potilaaseen otetaan vuorovaikutuksessa jatkuvasti huomioon. Potilashaastattelun vaiheiksi he erottavat 1) aloituksen, 2) tietojen keräämisen, 3) fyysisen tutkimuksen, 4) tietojen selittämisen, yhteisen päätöksenteon ja hoidon suunnittelun sekä 5) lopetuksen. Näiden vaiheiden mukaan he myös jäsentävät lääkärin tarvitsemia vuorovaikutustaitoja.

Keskeisiä vuorovaikutukseen liittyviä tehtäviä potilashaastattelussa ovat informaation vaihtaminen sekä suhteen luominen ja suhdekeskeinen viestintä (Cegala, McGee \& McNeilis 1996, 4). Vastaanoton aikana lääkärin tehtävänä on saada selville tietoa potilaasta ja ymmärtää potilaan kertoma tarina, koska se tarjoaa vihjeitä diagnoosiin ja hoidon kannalta olennaisiin seikkoihin, jotka liittyvät potilaan ongelmiin (Smith \& Hoppe 1991, 470). Informaation vaihtamiseen liittyy lääkärin näkökulmasta tarkan potilaskertomuksen ja sairaushistorian selvittäminen, lääketieteellisen ongelman kuvaaminen ja ymmärtäminen, diagnoosista ja hoitovaihtoehdoista kertominen sekä hoito-ohjeiden perusteleminen ja ymmärtäminen (Cegala, McGee \& McNeilis 1996, 4). Potilaan näkökulmasta informaation vaihtamiseen liittyy tarve tietää ja ymmärtää esimerkiksi se, mikä on vikana tai mistä kipu johtuu, sekä tarve tulla kuulluksi ja ymmärretyksi ja varmistua siitä, että lääkäri suhtautuu häneen vakavasti (Ong ym. 1995, 904). Suhteen luomiseen ja suhdekeskeiseen viestintään liittyy potilaskeskeinen lähestymistapa, jota tarkastellaan seuraavassa.

Potilashaastattelussa on erotettu lääkärikeskeinen ja potilaskeskeinen lähestymistapa, joista lääkärikeskeinen lähestymistapa on perinteisempi. Lääkärikeskeisesti työskentelevä lääkäri johdattaa keskustelua ja pitäytyy omassa toimintasuunnitelmassaan (Smith \& Hoppe 1991, 470). Potilaskeskeisesti tai suhdekeskeisesti työskentelevä lääkäri kuuntelee potilasta, antaa potilaan johdattaa keskustelua ja on kiinnostunut potilaan näkökulmasta, hänen tarpeistaan ja huolistaan, jolloin lääkärin ja potilaan suhde näyttäytyy 
tasa-arvoisena (Williams, Weinman \& Dale 1998, 486). Lääkäri käyttää avoimia kysymyksiä, kysyy potilaan mielipiteitä sekä neuvoo ja kertoo tietoja asioista, joista potilas haluaa kuulla (Smith \& Hoppe 1991, 470). Tutkimusten mukaan potilaiden tyytymättömyyttä hoidon suhdekeskeiseen puoleen aiheuttaa liian vähäiseksi koettu palaute, lääkärin tunteettomuus tai välinpitämättömyys, lääkärin väärät tulkinnat suhdekeskeisen viestinnän tarpeista, empatian osoittamisen puute ja se, jos lääkäri ei huomioi potilasta päätöksenteossa (Kreps 1988, Cegalan, McGeen \& McNeilisin 1996, 5 mukaan). Suhdekeskeinen viestintä vaikuttaa myös luottamuksen syntymiseen, lojaalisuuteen, arvostukseen ja yleiseen tyytyväisyyteen terveydenhuoltoa kohtaan (Cegala, McGee \& McNeilis 1996, 5). Sekä lääkärikeskeinen että potilaskeskeinen lähestymistapa voidaan yhdistää potilashaastattelussa ja niitä voidaan käyttää tarkoituksenmukaisella tavalla siten, että potilas johdattaa keskustelua niissä asioissa, joissa hän on asiantuntija (omat oireet, tuntemukset, huolet, toiveet ja arvot), ja lääkäri niissä asioissa, joissa hän on asiantuntija (lääketieteellinen tietämys ja diagnoosin tekeminen) (Smith \& Hoppe 1991).

Viestintäosaamiseen kuuluu tieto ja ymmärrys siitä, mitä tehokkaan ja tarkoituksenmukaisen vuorovaikutuksen onnistumiseksi tarvitaan (ks. Spitzberg \& Cupach 1984; Valkonen 2003). Voisi ajatella, että vuorovaikutukseen liittyvä teoreettinen tieto sekä lääkärin ja potilaan välistä vuorovaikutusta käsitteleviin tutkimuksiin perehtyminen auttavat lääkäriä tehokkaampaan ja tarkoituksenmukaisempaan vuorovaikutukseen potilaidensa kanssa (tutkimuksista ks. esim. Ong ym. 1995; Raevaara 2000; Ruusuvuori 2000). Metakognitiiviset tietojen avulla lääkäri voi reflektoida ja säädellä omaa toimintaansa, eli käyttää metakognitiivisia taitojaan oman toimintansa tavoitteelliseen ohjaukseen (ks. Rauste von Wright \& von Wright 1994).

Lääkärin viestintäosaamiseen kuuluvat myös vuorovaikutustaidot. Street $(2003,912)$ määrittelee vuorovaikutustaidon terveydenhuollon kontekstissa seuraavasti: "Interpersonal communication skill refers to the participants' ability to produce communicative 
responses that enhance both the quality and outcome of medical consultations." Vuorovaikutustaito viittaa siis osapuolten kykyyn viestiä siten, että vuorovaikutus parantaa sekä lääkärin vastaanoton laatua että tuloksia. Tutkimuksissa on havaittavissa hajanaisuutta lääkärin vuorovaikutustaitojen määrittelyssä. Cegala ja Broz (2003) tarkastelivat 26 tutkimusta, jossa käsiteltiin lääkärin vuorovaikutustaitoja ja niiden opettamista. Heidän mukaansa vuorovaikutustaitoja on tutkimuksissa jäsennetty esimerkiksi erottamalla toisistaan informaation välittäminen ja suhteen rakentaminen tai järjestämällä vuorovaikutustaidot potilashaastattelun mukaan. Tutkimuksissa ei kuitenkaan ollut yhteneväistä linjaa lääkärin tarvitseman viestintäosaamisen määrittelyssä, vuorovaikutustaitojen jäsentämisessä tai taitojen arvioinnissa.

Potilashaastattelun yhteydessä lääkärin vuorovaikutustaitoihin on katsottu kuuluvan esimerkiksi tietojen saaminen potilaalta, katsekontaktin käyttäminen, kysymysten käyttö, informaation jakaminen, suhteen luominen potilaaseen, hoitovaihtoehtoista keskusteleminen, päätöksenteontaidot, supportiivisen viestinnän taidot sekä potilaskeskeisen haastattelun taidot (Kurtz, Silverman \& Draper 2005; Maguire \& Pitceathly 2002; Smith ym. 2000; Street 2003). Erilaiset taitolistaukset havainnollistavat lääkärin työssään tarvitsemia vuorovaikutustaitoja, mutta ne eivät yksistään riitä kuvaamaan lääkärin viestintäosaamista.

Viestintäosaamisen yhtenä ulottuvuutena on nähty motivaatio käyttäytyä tavalla, jonka viestintätilanteen osapuolet näkevät tehokkaana ja tarkoituksenmukaisena (Rubin 1990, 96). Viestintäosaamisen affektiivisen ulottuvuuden tarkastelussa on tärkeää huomioida, että taitavastikaan viestivän henkilön taidot eivät näy eivätkä vaikuta, ellei hän halua, uskalla tai motivoidu osallistumaan vuorovaikutukseen ja käyttämään niitä (Valkonen 2003, 37). Lääkärin viestintäosaamisen tarkastelun yhteydessä tämä voisi esimerkiksi tarkoittaa, että lääkäri on motivoitunut potilaan haastattelemiseen, etsimään tietoa potilaan terveydentilasta, varmistamaan ymmärrystä, neuvottelemaan hoitovaihtoehdoista ja käyttämään 
potilaskeskeistä lähestymistapaa saadakseen selville potilaan ongelman ja tehdäkseen tarkan diagnoosin.

Valkosen $(2003,39)$ mukaan kompetenssin affektiivisen ulottuvuuden oheen tulisi liittää myös viestinnän eettisten periaatteiden tarkastelu. Läkärin vuorovaikutusosaamisen yhteydessä tämä tarkoittaisi kyvykkyyttä ja halukkuutta moraaliseen vastuuseen sekä viestinnän eettisten periaatteiden ja ongelmien ratkaisukykyyn. Kehittyvä lääketiede on tehnyt mahdolliseksi toimintoja, joiden oikeutusta joudutaan pohtimaan, mikä puolestaan aiheuttaa eettisten ongelmien lisääntymistä (Vainiomäki 1995, 23). Suomen Lääkäriliiton valtuuskunta on laatinut lääkärin työhön liittyvät eettiset periaatteet (Saarni 2005), joiden taustalla on ajatus siitä, että lääkärin tehtävästä ei voi suoriutua, ellei lääkärillä ole perusteellisten tietojen ohella vakavaa halua noudattaa eettisiä velvoituksia. Vuorovaikutukseen liittyen lääkärin eettisiin ohjeisiin on kirjattu muuan muassa, että lääkärin on kohdeltava potilaitaan tasa-arvoisina, lääkäri ei saa käyttää arvovaltaansa siten, että potilaan oikeus määrätä itsestään joutuu uhanalaiseksi, ja lääkärin tulee noudattaa ja kehottaa alaisiaan noudattamaan vaitiolovelvollisuutta. Jos lääkäri toivoo potilaansa osallistuvan lääketieteelliseen tutkimukseen, jossa poiketaan tilan normaalista tutkimuksesta tai hoidosta, lääkärin on saatava siihen potilaalta suostumus. (Saarni 2005.) Lääkärin viestintäosaamisen eettisiin periaatteisiin kuuluu siis se, että lääkäri on tiedostanut ammattiinsa kuuluvat eettiset ohjeet ja sitoutuu noudattamaan niitä ollessaan vuorovaikutuksessa potilaidensa kanssa.

Vaikka viestintäosaamista on tutkittu paljon, ei viestintäosaamisen määrittelyssä tai arvioimisessa ole aina havaittavissa yhteneväisyyttä (Cegala \& Broz 2003). Cegalan, McGeen ja McNeilisin (1996, 2) mukaan abstrakteja kontekstista riippumattomia teoreettisia malleja on vaikea operationalisoida tutkimuksen tekemistä varten tarkasti. Sen vuoksi he valitsivat lääkärin ja potilaan viestintäosaamisen tutkimisen lähtökohdaksi Cegalan ja Waldron (1992) kontekstisidonnaisen viestintäosaamisen mallin. Mallissa painotetaan vuorovaikutuksen kontekstisidonnaisuutta, osapuolten havaittavaa viestintäkäyttäytymistä ja sitä, kuinka osapuolet asettavat ilmaisunsa koordinoidessaan tavoitteitaan. Osaava viestijä tulkitsee ja tuottaa viestejä, joiden avulla sekä 
omat että toisten tavoitteet on mahdollista saavuttaa vuorovaikutuksessa (Cegala, McGee ja McNeilis 1996). Cegalan, McGeen ja McNeilisin (1996) empiirisessä tutkimuksessa lääkärit ja potilaat arvioivat sekä omaa että toistensa viestintäosaamista lääkärin vastaanotolla. Tutkimus osoitti, että lääkärin viestintäosaamisen arvioinneissa sekä informaation vaihtaminen että suhteen luominen ovat tärkeitä osaamisen kriteerejä. Sen sijaan potilaiden tärkeimmäksi viestintäosaamisen osatekijäksi nähtiin informaation välittäminen sekä omasta sairaudesta ja sairaushistoriasta kertominen. Tämänkaltainen tarkastelutaso kertoo mielestämme jotain siitä, ettei lääkäri tai potilas voi olla osaava viestijä yksin, vaan taitavuus rakentuu ja määrittyy yhteistyössä vuorovaikutuksen toisen osapuolen kanssa.

\section{VIESTINTÄOSAAMINEN POLIITIKON TEHTÄVÄSSÄ}

\section{Tutkimuksen lähtökohtia}

Poliitikkojen viestintää ja viestintätaitoja on tarkasteltu jo antiikin ajoista lähtien. Etenkin Aristoteles on tarkastellut viestintää ja sen onnistumisehtoja poliittisessa puheessa ja luonut havaintojensa pohjalta poliitikkojen viestintäosaamista kokonaisvaltaisesti käsittelevän retoriikan teorian (Aristoteles 1997, ix). Palosen $(2002,65)$ mukaan poliitikon pätevyyden määrittelystä haastavaa ja vaikeaa tekee se, että poliitikko ei ole "oikea" ammatti. Poliittinen pätevyys ei välttämättä hänen mukaansa ole tutkintojen, tiedon, asiantuntemuksen tai edes tieteen tuottamaa pätevyyttä. On silti selvää, että viestinnällä ja vuorovaikutuksella on erityisen keskeinen rooli poliitikon tehtävässä.

Vaikka poliitikon pätevyyttä on aikaisemmassa tutkimuksessa pyritty jonkin verran määrittelemään ja kuvailemaan, ei poliitikon viestintäosaamista ole kuitenkaan tiettävästi tutkittu paljonkaan ainakaan puheviestintätieteellisestä, vuorovaikutusta ja suhteiden luomista korostavasta näkökulmasta. Poliitikkojen viestintää tarkasteltaessa huomio on perinteisesti kiinnitetty vaikuttamisen ja vakuuttamisen taitoihin, vaalikampanjaviestintään tai vaikkapa imagon luomiseen ja ylläpitämiseen (ks. esim. Kaid 2004). Tällöin huomio on useimmiten poliitikon 
oman menestyksen tai onnistumisen tasolla, jolloin suhdeaspekti, toisten kanssa vuorovaikutuksessa toimiminen, jää vähemmälle huomiolle. Jottei poliitikon viestintäosaamisen tutkimus jäisi ainoastaan vaikuttavien viestintätaitojen tarkastelun tasolle, on ilmiötä syytä tarkastella myös hieman laajemmin ja kokonaisvaltaisemmin muun muassa suhteiden luomisen ja ylläpitämisen, viestinnän motiivien, asenteiden ja eettisten periaatteiden näkökulmasta. Tätä kautta pyrkimyksenämme on herättää keskustelua aihepiirin keskeisyydestä niin puheviestintätieteessä kuin osana modernin demokratian haasteiden ymmärtämistä.

\section{Viestintäosaamisen korkeat ihanteet}

Selkeys, ymmärrettävyys, tarkkuus, rehellisyys, suoruus, asiantuntevuus ja johdonmukaisuus ovat määreitä, joilla taitavaa viestintäkäyttäytymistä kuvaillaan (Valkonen 2003, 38). Tällaiset viestintäosaamiselle asetetut korkeat ihanteet ovat mielenkiintoinen lähtökohta poliitikkojen viestintäkäyttäytymisen tarkastelulle. Määreet palautuvat habermasilaiseen, inhimillisen toiminnan rationaalisuutta ja yhteistyöhakuisuutta korostavaan normatiiviseen, diskurssietiikaksi kutsuttuun ajattelutapaan, jonka mukaan ihminen on luonnostaan halukas ja kykenevä rehelliseen, totuudelliseen ja oikeudenmukaiseen viestintään eli kommunikatiiviseen toimintaan yhteisön muiden jäsenten kanssa löytääkseen toimintatapoja ja näkemyksiä koskevan yhteisymmärryksen (ks. Habermas 1987, Reunanen 2003, 23-24). Habermasilaista näkemystä kuvataan usein ideaaliseksi, optimistiseksi ja normatiiviseksi kuvaukseksi ihmisluonnosta ja demokraattisen toiminnan mahdollisuuksista (Reunanen 2003, 23-24).

On huomionarvoista, kuinka usein huomiomme kiinnittyy siihen, kuinka ristiriidassa - tai jopa päinvastaista - poliitikkojen viestintä tai puhe on suhteessa tällaisiin taitavaa ja osaavaa viestintää kuvaaviin teoreettisiin luonnehdintoihin. Aivan arkielämässäkin poliitikkojen viestintä tuntuu jatkuvasti herättävän keskustelua, hämmästelyä ja erityisesti kritiikkiä. Usein huomiomme kiinnit- 
tyy siihen, kuinka poliitikot - tietoisesti tai tiedostamattaan - rikkovat edellä kuvatun kaltaisia taitavalle viestintäkäyttäytymiselle asetettuja ihanteita tai kriteereitä. Poliitikkojen puhe samaistetaan usein jopa omaksi kielityypikseen, jossa manipulointi, katteettomat lupaukset, hämärät käsitteet tai ympäripyöreä puhe ovat sallittuja ja jokapäiväisiä (Paloheimo \& Wiberg 1997). Poliitikon ajatellaan usein olevan omaa etuaan ajava ja vallanhimoinen toimija, jonka tärkeimpänä tehtävänä on oman edun ja menestyksen maksimointi. Politiikka saattaakin usein näyttäytyä tarkoitushakuisena kilpailuna, jossa poliitikon henkilökohtaiset tavoitteet menevät ryhmän etujen edelle. Pelko oman aseman menetyksestä saa vallanpitäjät pelaamaan likaista peliä, jonka pelinappuloita kansalaiset ovat. Pahimmillaan kansalaisista tulee ainoastaan voiton tavoittelun välineitä tai kohteita, joiden äänistä käydään kilpailua. (Ks. esim. Reunanen 2003, 26-27.) Vaikka tämänkaltaiset väittämät saattavat kuulostaa vahvoilta tai jopa liioitelluilta, eivät ne kuitenkaan pohjimmiltaan liene täysin vieraita poliittiselle elämälle tai inhimilliselle toiminnalle ylipäätään, jolle kuuluisan machiavellistisen reaalipoliittisen näkökulman mukaan leimallista on häikäilemätön ja itsekäs vallan tavoittelu (ks. esim. Kanerva 1992). Lisäksi nykypäivänä poliittisen viestinnän medialisoituminen osaltaan yhä enemmän kärjistää, raaistaa ja viihteellistää poliittista keskustelua (esim. Isotalus 2001).

Osaavana pidetään sellaista viestintäkäyttäytymistä, joka mahdollistaa omien tavoitteiden saavuttamisen mutta sallii myös toisten saavuttaa omia tavoitteitaan; joka mahdollistaa ymmärtämisen ja jonka avulla yksilöt tai ryhmät pääsevät tulokseen niin, että yhteisyys, ymmärrys, tyytyväisyys ja yhteishenki kasvavat sosiaalisessa yhteisössä (Spitzberg \& Duran 1994, Valkosen 2003, 38 mukaan). Politiikan kentältä on varmasti löydettävissä lukuisia esimerkkejä, joissa viestinnän päämäärät ovat täysin päinvastaisia tällaiselle osaavaa viestintä- ja vuorovaikutuskäyttäytymistä koskevalle luonnehdinnalle. On esimerkiksi olemassa näyttöä siitä, että poliitikot ovat usein haluttomia avoimeen keskusteluun. Pietilän (2002) mukaan esimerkiksi verkossa tapahtuva sähköinen vuorovaikutus 
poliitikkojen ja kansalaisten välillä on monella tapaa ongelmallista. Hänen mukaansa päättäjät ovat usein vastahakoisia keskustelemaan tavallisten kansalaisten kanssa laajemmassa julkisuudessa pelätessään kasvojensa menetystä tai kannatuksen vähentymistä. Muita vuorovaikutuksen ongelmia sähköisillä foorumeilla ovat hänen mukaansa keskustelun voittamisen pakko, lyhytjännitteisyys ja puolueellisuus. (Pietilä 2002, 352.) Bourdieun (2000, ks. Kauppi 2005,85 ) ajattelussa poliitikko monopolisoi puheen eli puhuu edustamansa ryhmän nimissä ja voi lopuksi manipuloida ryhmää sen omissa nimissä. Yhteisyyden, ymmärryksen, tyytyväisyyden tai yhteishengen lisääntymisen sijaan kansalaisesta tulee Bourdieun mukaan ainoastaan riiston kohde.

Keskeinen osa viestintä- ja vuorovaikutusosaamista on halu ja sitoutuneisuus viestinnän eettisten periaatteita noudattamiseen. Jokaisen henkilökohtaiseen viestintäosaamiseen kuulunee myös kyky tehdä osuvia päätelmiä ja tietoisia päätöksiä vuorovaikutustilanteissa siitä, miten oikeutettua ja moraalista toiminta on omien tavoitteiden ja toisten hyvinvoinnin kannalta. Taidokas viestintäkäyttäytyminen edellyttää tietoa, motivaatiota ja uskallusta osallistua vuorovaikutustilanteisiin sekä halukkuutta ja kykyä kantaa moraalista vastuuta teoistaan. (Valkonen 2003, 38-39.) Viestinnän vastuullisuus ja etiikka saavat keskeisen roolin myös normatiivisessa demokratiateoriassa. Erityisesti Habermasin (ks. esim. Habermas 1987) ajatteluun palautuvassa deliberatiivisessa demokratiakäsityksessä heijastuu vahvasti ajatus siitä, että harkitun keskustelun avulla on parhaimmillaan mahdollista ratkaista poliittisen yhteisön ongelmia sekä kehittää yhteiskuntaa paremmaksi (Reunanen 2003, 22). Ajattelutavan juuret ylettyvät syvälle länsimaisen ajattelun, valistuksen ja rationaalisuuden traditioon (Cooke 2000; Herne \& Setälä 2005, 175). Toteutuakseen deliberaation ihanteen mukaisena viestinnän tulee kuitenkin täyttää korkeita pätevyysvaateita, kuten väitteiden totuudellisuus, ymmärrettävyys ja rehellisyys, objektiivinen argumentointi, toisten kuunteleminen, keskinäinen kunnioitus ja puolueettomuus (Habermas 1987, 82; Jensen 2003). Parhaimmillaan deliberatiivisella keskustelulla on 
emansipatorinen merkitys, koska se vähentää valtaeroja, epäluuloa ja ennakkoluuloja vallanpitäjien ja kansalaisten välillä (Fishkin 1995). Deliberaation tuloksena on yhteiskunnan jäsenten kouliintuminen "todelliseen julkiseen ajatteluun ja poliittiseen arviointiin niin, että he pystyisivät hahmottamaan yhteistä tulevaisuutta paremmin yhteisen hyvän pohjalta" (Barber 1984, Pietilän 2002, 344 mukaan).

Hieman samansuuntaista, optimistista ihmis- ja yhteiskuntakäsitystä edustaa myös puheviestintätieteellinen lähestymistapa, jossa vuorovaikutuksen erilaisia määritelmiä yhdistää ihmisten välisen yhteyden ja vuorovaikutusosapuolten yhteisvastuullisen toiminnan korostaminen. "Vuorovaikutus nähdään prosessiksi, jossa yhdessä muokataan ja säädellään sosiaalista todellisuutta" (Kostiainen 2003,12 ). Vuorovaikutuksen ongelmat voivat yhteistyön merkitystä korostavasta näkökulmasta johtua siitä, että toinen tai molemmat osapuolet rikkovat viestintää ohjaavaa yhteistyön ja vastavuoroisuuden periaatetta (Littlejohn 2002, 76-87). Tällainen puheviestinnällinen, yhteistyön ja yhteisvastuun merkitystä korostava lähtökohta on varmasti tervetullut ja hyödyllinen näkökulma päättäjien viestintäosaamisen merkitysten hahmottamiselle ja teoreettiselle pohdinnalle. On kuitenkin tärkeää tulla tietoiseksi, että ajatus ihmisestä yhteistyökykyisenä, rehellisenä, totuudellisena ja oikeudenmukaisena toimijana perustuu tietynlaiselle, normatiivis-idealistiselle ihmis- ja yhteiskuntakäsitykselle. Tämä vaikuttaa implisiittisesti myös käsityksiimme ja määrityksiimme siitä, millaiseksi taitava, osaava ja tavoiteltava viestintäkäyttäytyminen jäsentyy. Politiikkaa ei kuitenkaan voida kokonaisvaltaisesti ymmärtää ainoastaan yhteistyöhön tai yhteisymmärryksen tuottamiseen pyrkivänä yhteistoimintana, vaan yhtä tärkeää on huomioida politiikan olemukseen sisältyvä raaka kilpailu vallasta, joka edellyttää strategiaa, pelisilmää ja taktikointia. Myös normatiivisen demokratiateorian korkeat, ja ehkäpä myös turhan idealistisetkin, ajatukset demokratian mahdollisuuksista tulisi asettaa vertailuun muunlaisten demokratia- ja politiikkakäsitysten kanssa. Esimerkiksi pessimistisen ihmis- ja politiikkakäsityksen mukaan politii- 
kan olemukseen kuuluu erimielisyys, kilpailu, valtataistelu ja ristiriidat. Politiikka etenee ratkaisusta ongelmaan, eikä sen avulla voida tämän näkemyksen mukaan saada aikaan yhteiskunnallista edistystä. Pessimistisen politiikkakäsityksen mukaan demokratian toteutuminen tai edistyminen, mikäli se määritellään kansan mielipiteistä lähteväksi kollektiiviseksi ja vuorovaikutteiseksi päätöksenteoksi, on itsessään mahdottomuus (Edelman 1988, Reunasen 2003, 26 mukaan). Pessimististä ihmis- ja demokratiakäsitystä edustaa myös Robert Michelsin $(1986,43)$ kuuluisaksi tullut "oligarkian rautainen laki", joka viittaa demokratian mahdottomuuteen, sillä hänen mukaansa kaikilla organisaatioilla, olipa ne tarkoitettu kuinka demokraattisiksi tahansa, on aina ajan mittaan taipumuksena muuttua oligarkioiksi, harvainvalloiksi (Kyntäjä 1989, 117).

Tällainen jännite niin viestintäosaamisen kuin normatiivisen demokratianäkemyksen teoreettisiin määritelmiiin liittyvien korkeiden eettisten ihanteiden ja reaalipolitiikan välillä tekee päättäjien viestintäosaamisen tarkastelusta entistä mielenkiintoisempaa. Erityisen kiinnostavaa olisi tarkastella, millaisena tämä jännite tai kontrasti näyttäytyy yksittäisten poliitikkojen kokemuksissa, kokemusmaailmassa ja käsityksissä omasta viestintäosaamisestaan, sen heikkouksista, vahvuuksista ja erityishaasteista. Lienee ainakin perusteltua olettaa, että pyrkimys noudattaa ja toteuttaa omassa viestintäkäyttäytymisessä edellä kuvatun kaltaisia korkeita eettisiä ihanteita saattaa osoittautua erittäin haasteelliseksi politiikan kilpailullisessa maailmassa, jota usein kuvaillaan itsekkääksi vallan tavoitteluksi, likaiseksi peliksi, oman edun maksimoinniksi tai manipulaatioksi.

\section{Miten jäsentää poliitikon viestintäosaamista?}

On selvää, että puheviestinnällisellä lähestymistavalla on paljon annettavaa viestintäosaamisen tutkimukselle politiikkaa ja erityisesti poliitikkojen toimintaa tarkasteltaessa. Usein puhutaan kansalaistaidoista tai valistuneesta kansalaisesta, "demokratian ritarista", joka seuraa aktiivisesti ja tietoisesti poliittista päätöksen- 
tekoa, vaikuttaa siihen ja kontrolloi päättäjien toimintaa (ks. esim. Paloheimo 2005). Yhtä tärkeää olisi kuitenkin kiinnittää huomiota myös poliitikkojen osaamiseen ja velvollisuuksiin päätöksentekijöinä ja yhteiskunnallisina auktoriteetteina. Poliitikon osaaminen, erityisesti viestintäosaaminen, tulisikin nostaa selvemmin esille modernin demokratian ja erityisesti kansalaisten ja poliitikkojen välisen suhteen ongelmia tarkasteltaessa (Finstad \& Isotalus 2005).

Max Weber (1964) näkee poliittisen johtajuuden demokratian onnistumisen keskeisenä ehtona (Pekosen 1989, 186, 190 mukaan). Weberin ajattelussa ideaali poliitikko on karismaattinen johtaja, jolla on kyky merkityksellistää asioita, kirvoittaa keskustelua, luoda uusia näkökulmia ja tätä kautta saada aikaan yhteisiä arvoja koskevaa pohdintaa. Hänen mukaansa poliitikon tärkeimpiä ominaisuuksia ovat "intohimoinen omistautuminen toiminnan vaikuttimelle, asialle; suhteellisuuden taju, joka edellyttää kylmää harkintaa ja etäisyyttä asioihin ja ihmisiin sekä vastuuntunto, joka edellyttää henkilökohtaisen vastuun ottamista tekemisistään" (Weber 1964, 84-85, Pekosen 1989, 190 mukaan).

Viestintäosaamisen keskeisimmiksi ulottuvuuksiksi luetaan usein tiedot, taidot, motivaatio, eettisten periaatteiden hallinta, metakognitiiviset taidot, asennoituminen ja ymmärrys (Kostiainen 2003, 141; Valkonen 2003, 26). Jos tätä määritelmää rinnastetaan Weberin (1964) poliittisen johtajan kykyjä koskevaan määritelmään, voidaan huomata tiettyjä yhteneväisyyksiä. Edellä mainituista osa-alueista erityisesti motivaatio (intohimoinen omistautuminen), etiikka ja vastuu (vastuuntunto, joka edellyttää henkilökohtaisen vastuun ottamista tekemisistä) sekä ymmärrys ja asennoituminen (kylmä harkinta, joka edellyttää etäisyyttä asioihin ja ihmisiin) tulevat ilmi Weberin määritelmässä taitojen ja tietojen jäädessä sen ulkopuolelle. Poliitikon viestintäosaamista ei tulisikaan tarkastella ainoastaan tarkkarajaisina taitoina tai strategioina, vaan yhtä tärkeää olisi huomioida viestintäosaamisen "syvätaso". Viestintäosaamista ei täten tulisi tarkastella yksittäisinä vaikuttavan viestinnän taitoina ja taktiikoina tai poliittisena pelisilmänä, 
vaan laaja-alaisena ihmissuhteisiin ja kanssakäymiseen liittyvänä kompetenssina, joka pitää sisällään eettisen ja itsereflektiivisen osa-alueen sekä kyvyn arvioida omaa käyttäytymistä kriittisesti ja ennakkoluulottomasti moraalin, oikeudenmukaisuuden ja luotettavuuden näkökulmasta. Viestintäosaaminen on laaja-alainen osaamisalue, joka yltää myös ihmisen mielensisäisiin ja tiedostamattomiin rakenteisiin. Pohjimmiltaan viestintäosaaminen on kaikenlaisen ammattiosaamisen ydinaluetta (Kostiainen 2003). Se ei tarkoita ainoastaan sujuvia viestintätaitoja vaan pitää yhtä lailla sisällään viestintämotivaation sekä itsereflektiivisen kyvyn oman toiminnan arviointiin ja ymmärtämiseen myös etiikan ja vastuuntunnon näkökulmasta.

Erityisesti relationaalinen, viestintäsuhdetta korostava lähestymistapa soveltunee tarkoituksenmukaisesti lähtökohdaksi päättäjien viestintäosaamisen funktioiden hahmottamiselle. Poliitikkojen viestintäosaamisen tarkastelun lähtökohdaksi lienee luontevaa valita poliitikkojen ja kansalaisten välinen suhde, joka muodostaa edustuksellisen demokratian perustan. Edustuksellisessa järjestelmässä poliitikon ja kansalaisten välillä vallitsee molemminpuolinen riippuvuussuhde siinä mielessä, että poliitikot saavat toimintansa oikeutuksen äänestäviltä kansalaisilta, jotka vastavuoroisesti odottavat poliitikon kantavan huolta heille tärkeistä asioista. Kansalaiset ovat vuorovaikutussuhteessa erityisessä roolissa: perustana, josta kansanvalta saa alkunsa. Edustuksellisessa järjestelmässä poliitikkojen rooli päätöksentekijänä ja vallanpitäjänä kuitenkin korostuu, sillä kansalainen siirtää valtaansa edustajalleen päätöksentekoprosessin tehostamiseksi (Paloheimo \& Wiberg 1997). Näin ollen luottamuksen merkitys kansalaisten ja päättäjien suhteessa korostuu (Setälä 2003). Kuten lääkärin ammatissa, myöskään poliitikon tehtävässä viestintäosaamisen tai taitavuuden ei näin ollen voida ajatella rakentuvan yksilössä itsessään vaan nimenomaan vuorovaikutuksessa viestinnän muihin osapuoliin, poliitikon tehtävässä laajimmillaan koko yhteiskuntaan. 
Poliitikkojen ja kansalaisten suhdetta ei liene syytä, tai edes mahdollista, tarkastella suorana interpersonaalisena viestintäsuhteena, vaan näkökulmaa lienee syytä laajentaa ja abstrahoida. On syytä ottaa huomioon, että poliitikkojen ja kansalaisten välinen suhde on huomattavan kompleksinen ja myös monin tavoin problemaattinen tutkimuksellinen lähtökohta. Tultaessa 2000-luvulle mediasta on tullut poliittisen informaation pääasiallisin lähde (ks. esim. Mazzoleni \& Schultz 1999). Mediasta onkin tullut äänestäjän ja poliitikon vuorovaikutuksen keskeisin välikappale (Isotalus 2001). Media muotoilee ja säätelee poliittista päätöksentekoa sekä vaikuttaa myös itse siihen suuressa määrin. Myös kansalaisten poliittinen osallistuminen saa jatkuvasti uusia ruohonjuuritason muotoja samalla kun edustuksellinen järjestelmän painoarvo ja vaikuttavuus poliittisen osallistumisen kohteena vähenee (Lappalainen 2002). Ei siis voida yksioikoisesti ajatella, että politiikka modernissa yhteiskunnassa toteutuisi ainoastaan - jos ollenkaan - päättäjien ja kansalaisten välisenä vuoropuheluna.

Ehkäpä tarkoituksenmukaisempaa ja yksiselitteisempää olisikin kiinnittää huomiota yksinomaan poliitikkojen kansalais- tai yhteiskuntasuhteeseen eli poliitikoilta kansalaisille päin suuntautuvaan viestintäsuhteeseen. Valkonen (2003, 26-27) puhuu osuvasti yksilön yhteiskuntasuhteesta viestintä- ja vuorovaikutusosaamisen perusyksikkönä. Tämä lähtökohta soveltuukin tarkoituksenmukaisesti poliitikkojen viestintäosaamisen jäsentämisen lähtökohdaksi; toimivathan poliitikot näkyvässä yhteiskunnallisessa auktoriteettiasemassa olevina vaikuttajina. Puhuttaessa relationaalisesta kompetenssista viestintäosaamisen tuloksia tarkastellaan suhteen tasolla; kyseessä ei silti ole niinkään suhde tiettyyn yksilöön vaan nimenomaan yhteiskuntasuhde (Valkonen 2003, 34).

Jos päättäjien ja kansalaisten suhdetta tarkastellaan vuorovaikutus- tai yhteistyösuhteena, voidaan useita modernin demokratian ongelmia, kuten matalaa äänestysaktiivisuutta, pitää osoituksena siitä, että toinen osapuolista tai kummatkin eivät vastavuoroisesti täytä velvollisuuksiaan suhteessa toiseen. Usein ensisijaisimmaksi syyksi nähdään juuri kansalaisten passiivisuus ja matala osallistu- 
mishalukkuus (ks. esim. Paloheimo 2005). Edustuksellisen järjestelmän kohdatessa ongelmia huomiota tulisi kiinnittää kansalaisten lisäksi yhtä lailla päättäjien toimintaan. Vuorovaikutus kansalaisten kanssa olisi kuitenkin tärkeää nähdä yhä keskeisempänä osana poliitikkojen tehtävää. Päättäjien ja kansalaisten välisen vuorovaikutuksen vähäisyys, luottamuksen puute sekä kansalaisen merkityksellisten osallistumismahdollisuuksien parantaminen poliittisessa päätöksenteossa asettavatkin erityishaasteita erityisesti poliitikkojen viestintäosaamiselle.

Parhaimmillaan poliitikkojen viestintäosaaminen olisi yhteistyötaitoa, kuuntelutaitoa, luottamuksen rakentamista sekä jatkuvaa eettistä harkintaa ja itsereflektiota. Erityisen haastavaa poliitikkojen viestintäosaamisen tarkastelusta tekee, että suhde yhteiskuntaan tai kansalaiseen on monella tapaa vaikeasti määriteltävä ja paikannettava, monitahoinen, välittynyt ja abstrakti. Kyseessä ei siis ole selkeä kasvokkainen viestintätilanne tai edes viestintätilanne, jossa vastaanottaja olisi aina selvillä. Laajimmillaan poliitikkojen viestintä on suunnattu koko yhteiskunnalle, joten se saattaa olla sävyltään ja tavoitteiltaan hyvinkin kirjavaa ja erilaisiin päämääriin pyrkivää. Tämä tekee poliittisen pätevyyden ja viestintäosaamisen määrittelystä vaikeaa ja haastavaa (Palonen 2002, 65). Silti suhde päättäjän ja kansalaisen, vallanpitäjän ja vallanluovuttajan, välillä on demokratian keskeisin peruselementti, joka on kautta historian herättänyt kiinnostusta mitä erilaisimmista näkökulmista. Poliitikon ja kansalaisen suhdetta voidaankin tarkastella ennen kaikkea pitkäkestoisena perustavanlaatuisena valtasuhteena, jossa kysymykset vallan jakautumisesta, luottamuksesta, vastuusta ja demokratiasta ovat aina läsnä.

Tärkeä kysymys on, miten voimme saada tietoa poliitikkona toimivien henkilöiden viestintäosaamisesta. Miten viestintäosaamista ylipäätään on mahdollista arvioida tai miten tulla tietoiseksi ja päästä käsiksi sen sisältöihin, ymmärtää ja käsitteellistää sitä? Entä miten kehittää viestintäosaamista tai tulla tietoiseksi sen heikkouksista? Viestintäosaaminen on pitkälti hiljaiseen tietoon perustuva 
alue, jonka käsitteellistäminen edellyttää kykyä monipuoliseen itsereflektioon. Eräs tapa tarttua aihepiiriin on kiinnittää huomiota poliitikkojen omiin käsityksiin omasta viestintäkäyttäytymisestään ja peilata niitä edellä käsiteltyjä teoreettisia kehyksiä vasten. Tärkeää olisi myös saavuttaa tarkastelutaso, joka huomioi motiivit viestintä- ja vuorovaikutuskäyttäytymisen taustalla.

\section{VIESTINTÄOSAAMISESTA VUOROVAIKUTUSOSAAMISEEN?}

Lääkärin ja poliitikon tehtävissä on pohjimmiltaan kyse hyvin erityyppisistä toimintakonteksteista. Tärkeä kysymys on, onko tehtävien välillä ylipäätään mitään yhdistäviä tekijöitä viestinnän ja viestintäosaamisen näkökulmasta. Ovatko poliitikon tehtävä ja lääkärin ammatti viestintäosaamisen näkökulmasta keskenään jopa eräänlaisia ääripäitä? Lääkärin ammattia voidaan pitää perinteisenä professiona, jossa tavoitteet ovat useimmiten selkeät ja eriytyneet ja jossa viestinnän ja vuorovaikutuksen päämäärät potilaan kanssa ovat useimmiten selkeät (Antikainen 1998). Esimerkiksi lääkärin vastaanotolla tapahtuvassa potilashaastattelussa kummatkin vuorovaikutusosapuolet ovat pääsääntöisesti tiedossa ja läsnä, jolloin voidaan puhua selkeästi kasvokkaisesta viestintäsuhteesta. Poliitikkona toimimista ei voida yhtä selkeästi rinnastaa perinteiseen professioon, vaan kyseessä on yhteiskunnallinen luottamustehtävä, jossa viestinnän tavoitteet ovat monella tapaa eriytymättömämpiä ja mahdollisesti laaja-alaisempia kuin lääkärin ammatissa. Myös viestinnän päämäärät lienevät monilta osin heterogeenisemmat kuin lääkärin ammatissa. Poliitikon tehtävässä ei myöskään välttämättä muodostu yhtä selkeärajaisia interpersonaalisia vuorovaikutussuhteita tai kohtaamistilanteita kuin lääkärin ammatissa, joten viestinnän vastaanottaja ei aina ole samalla tavoin läsnä vuorovaikutussuhteen toisena osapuolena. Poliitikon viestintä voi yhtä hyvin suuntautua yksilöille, ryhmittymille kuin koko yhteiskunnalle ja toteutua mitä erilaisimpia kanavia pitkin, niin kasvokkaisena kuin erilaisissa medioissa käytävänä julkisena keskusteluna tai tiedotteina. Näin ollen poliitikkojen viestintä on luonteeltaan 
ehkä yksisuuntaisempaa, tietylle yleisölle suunnattua tiedottamista verrattuna lääkärin ammattiin, jossa toimitaan tiiviissä kasvokkaisessa vuorovaikutuksessa potilaan kanssa. Poliitikolla on myös useampia viestintäkanavia käytettävissään, joista jokainen asettaa erityishaasteensa viestintäosaamiselle. Esimerkiksi kyky hyödyntää erilaisia medioita, tiedottaa tai esiintyä korostuu poliitikon tehtävässä.

Eroista huolimatta sekä lääkärin että poliitikon tehtävää voidaan toisaalta selkeästi pitää tehtävinä, joissa kummassakin viestinnässä toimimisen ja viestintäosaamisen merkitys nimenomaan korostuu. Lisäksi huomionarvoista on, että sekä lääkärin että poliitikon tehtävissä valta-asetelmiin ja hierarkiaan liittyvät kysymykset ovat aina läsnä. On selvää, että kummassakin kontekstissa kysymykset vastuusta, valta-aseman oikeudenmukaisesta käytöstä sekä tehtävässä toimivan henkilön kyvystä eettisten asioiden harkintaan ja itsereflektioon nousevat keskeiseen rooliin viestintäosaamisen käsitettä tarkasteltaessa.

Keskeinen näkökulma, joka yhdistää sekä poliitikon ja lääkärin tehtäviä viestintäosaamisen näkökulmasta, on suhde asiakkaaseen. Tässä artikkelissa viestintäosaamisen tarkastelun erääksi punaiseksi langaksi ja yhdeksi eri tehtäviä yhdistäväksi piirteeksi muodostuikin juuri asiakaspalvelunäkökulma. Lääkärin ammatissa asiakassuhde tai potilassuhde on selkeärajainen: asiakas on aina tiedossa ja useimmiten myös kasvokkaisesti läsnä. Vaikka poliitikon tehtävässä asiakas, tai kansalainen, ei useinkaan välttämättä ole samoin tiedossa, on kyseessä silti selkeästi edustussuhde, jossa poliitikon tehtävän lähtökohtana on kansalaisten asian esiintuominen ja hoitaminen. Kummassakin tehtävässä on näin ollen jossain määrin kyse asiakaspalvelusta. Viestinnän kannalta on olennaista, että asiakkaan näkökulman huomioimiseen kuuluu se, että asiakkaalle annetaan tilaa osallistua ja hänen osallistumisensa otetaan huomioon vuorovaikutustilanteessa (Gerlander \& Takala 2000,167 ). Kummankin tehtävän perustana on täten vuorovaikutussuhde, joka lääkärin työssä on selkeämpi ja eriytyneempi kuin 
politiikassa, jossa mitä erilaisimpien yhteiskunnallisten alueiden ja kysymysten voidaan katsoa kuuluvan toimintakenttään.

Tarkastelumme perusteella voitaisiin ajatella, että juuri tällainen viestintäosaamisen relationaalinen, vuorovaikutussuhteisiin liittyvä ulottuvuus nousee selkeästi esille lääkärin ja poliitikon viestintäosaamista hahmoteltaessa etenkin silloin, kun lähtökohdaksi otetaan edellä kuvatun kaltainen asiakaspalvelunäkökulma. Tämånkaltaista osaamista kuvaa mielestämme osuvasti juuri vuorovaikutusosaamisen käsite. Lääkärin ammattia voidaan tarkastella professionaalisena ihmissuhdeammattina, jossa kontakti asiakkaaseen, tai potilaaseen, on tiivis ja perustuu välittömään kasvokkaiseen vuorovaikutukseen. Lääkärin viestintäosaamisessa yksittäisten viestintätaitojen sijaan tärkeäksi nouseekin vuorovaikutusosaaminen: kyky toimia toisen ihmisen kanssa, muodostaa ja pitää yllä tasavertainen, toista osapuolta kunnioittava ja luottamuksellinen suhde, joka huomioi herkästi ja kattavasti potilaan näkökulman sekä näin mahdollistaa hoitotavoitteisiin pääsyn. Tutkimuksissa onkin alettu tarkastella lääkärin tarvitseman viestintäosaamisen lisäksi myös potilaan viestintäosaamista sekä lääkärin ja potilaan tulkintoja toistensa osaamisesta (Cegala \& Broz 2003; Cegala, McGee \& McNeilis 1996; Street 2003).

Samaa ajatusta voitaisiin soveltaa myös poliitikon tehtävään: onhan poliitikko ennen kaikkea kansalaisen edustaja, joka on saanut toiminnalleen oikeutuksen kansalaisilta. Kiinnostavaa olisi tarkastella poliitikon viestintä- ja vuorovaikutusosaamista esimerkiksi tapana käyttää kansalaisilta lainaan saatua valtaa tai tapana asennoitua oman luottamustehtävän toteuttamiseen. Tällöin vuorovaikutusosaaminen ja sen puute voisi ilmetä sekä tulla arvioiduksi esimerkiksi päättäjän kykynä huomioida erilaisia näkökantoja tai kuulijaryhmien tarpeita, kykynä muotoilla omat viestit erilaisten yleisö- ja kuulijaryhmien mukaan, motivoitumisena kuuntelemaan ja huomioimaan muita osapuolia, halukkuutena asettua vuorovaikutukseen kansalaisten ja muiden sidosryhmien kanssa tai vaik- 
kapa tyylinä antaa tai olla antamatta palautetta sekä reagoida saatuun palautteeseen.

Tarkastelumme perusteella viestintä- ja vuorovaikutusosaamista voitaisiin myös pitää monilta osin kontekstisidonnaisena tai -riippuvaisena osaamisalueena, jonka tarkemmat päämäärät ja erityishaasteet muotoutuvat melko pitkälti kulloisenkin toimintakontekstin ja -tilanteen mukaan. Viestintäosaamisen tilannesidonnainen luonne tulee mielestämme erityisen selkeästi esiin, jos viestintäosaamista tarkastellaan relationaalisesta näkökulmasta. Tällöin huomio siirtyy viestijästä, esimerkiksi poliitikon julkisesta esiintymistaidosta vuorovaikutussuhteen tasolle. Keskeisimmäksi osaamisen haasteeksi muodostuu toisen kanssa toimiminen: toisen osapuolen huomioiminen tasavertaisena osallistujana viestintätilanteessa. Viestintäosaamisen keskiöön nousee kysymys siitä, miten sovittaa tehokkaalla ja tarkoituksenmukaisella tavalla yhteen kahden ihmisen mahdollisesti hyvinkin erilaiset lähtökohdat, viestintätyylit ja näkemykset niin, että luottamuksellinen vuorovaikutussuhde voidaan säilyttää ja yhteiset tavoitteet voidaan saavuttaa. Yksittäisten viestintätaitojen sijaan tämänkaltainen vuorovaikutusosaaminen edellyttänee ennen kaikkea tilanneherkkyyttä eli tilannekohtaista arviointikykyä, joka ei lukkiudu vakiintuneisiin asenteisiin tai tottumuksiin vaan kykenee hyödyntämään jokaisen vuorovaikutustilanteen ainutlaatuisuuden.

Yhteenvetona lääkärin ja poliitikon viestintäosaamisen tarkastelusta sekä viestintäosaamisen, viestintäkompetenssin, puheviestintäkompetenssin ja puheviestintäosaamisen teoreettisista määritelmistä (ks. esim. Valkonen 2003; Kostiainen 2003; Rubin 1990; Spitzberg \& Cupach 1984) tulimme siihen tulokseen, että vuorovaikutusosaamisella voidaan tarkoittaa yksilön kognitiivisia rakenteita, viestintään ja vuorovaikutukseen liittyviä tietoja, metakognitiivisia taitoja, vuorovaikutustaitoja, motivaatiota sekä viestintään liitettäviä eettisiä periaatteita ja niiden noudattamista. Vuorovaikutusosaaminen liittyy viestintäsuhteeseen, kehittyy ja määrittyy vuorovaikutussuhteessa. Vuorovaikutusosaaminen on tilannesi- 
donnaista ja siihen liittyy tehokkuuden ja tarkoituksenmukaisuuden näkökulma.

Viestintä- ja vuorovaikutusosaamisen tutkimiseen liittyy monia haasteita. Teoreettisena käsitteenä viestintä- ja vuorovaikutusosaaminen on erityisen laaja-alainen ja pitää sisällään monia ulottuvuuksia, jotka liittyvät tiiviisti niin yksilöpsykologisiin kuin moraalifilosofisiinkin kysymyksiin. Eräs keskeinen viestintäosaamisen käsitteellistämiseen liittyvä kysymys on, kuinka tai millaisin ehdoin on ylipäätään mahdollista asettaa normeja tai ihanteita osaavalle tai taitavalle viestinnälle. Kenellä on oikeus tai tarvittava kyky määritellä, millaista on osaava eli hyvä ja onnistunut viestintäkäyttäytyminen? On tärkeää tulla tietoiseksi siitä, että viestintäja vuorovaikutusosaamisen määrittelyyn liittyy aina normatiivinen ulottuvuus: pyrkimys tehdä ero taitavan ja taitamattoman, hyödyllisen ja haitallisen, tavoiteltavan ja epätarkoituksenmukaisen viestintäkäyttäytymisen välille. Tällaisten rajanvetojen teko edellyttänee aina taustakseen tarkkaa ja seikkaperäistä moraalifilosofista pohdintaa. Eräs suurimmista haasteista viestintäosaamisen tarkastelulle ja määrittelylle lieneekin juuri tällainen sidos ihmiskäsitykseen ja arvoihin. Kuten Lehtonen (1994, 49-50), osuvasti tiivistää, on viestintäosaamisen käsitettä määriteltäessä keskeistä pohtia myös "kuka ratkaisee viime kädessä, millainen on hyvä viestijä - tai millainen on hyvä ihminen?"

\section{LOPUKSI}

Tavoitteenamme oli pohtia, millaisia merkityksiä ja jäsennyksiä viestintäosaaminen saa tai voisi saada lääkärin ammatissa sekä osana poliitikon tehtävää. Tarkoituksena oli pohtia, millaista viestintäosaamista poliitikko ja lääkäri työssään tarvitsevat sekä miten viestintäosaamista voidaan jäsentää kahden erilaisen ammatillisen tarkastelukontekstin kautta. 
On selvää, että lääkärin ja poliitikon tehtävät edellyttävät monella tapaa hyvin erityyppistä osaamista. Myös viestinnän muodot, kanavat, kohteet sekä vuorovaikutuksen luonne ja päämäärät poikkeavat selkeästi toisistaan näissä toimintakonteksteissa. Näin ollen kumpaankin kontekstiin liittyy myös omanlaisia tutkimuksellisia haasteitaan. Lääkärin viestintäosaamista ja vuorovaikutustaitoja on tutkittu runsaasti, mutta tutkimuksissa ei ole havaittavissa selkeää yhtenäistä linjaa vuorovaikutustaitojen jäsentämisessä ja määrittelemisessä. Poliitikon viestintä- ja vuorovaikutusosaamista ei puolestaan ole tiettävästi tutkittu paljonkaan ainakaan puheviestintätieteellisestä, vuorovaikutusta ja suhteiden luomista korostavasta näkökulmasta.

Viestinnän ja vuorovaikutuksen merkitys on keskeinen sekä lääkärin ammatissa että poliitikon tehtävässä. Kun lääkärit käyttävät vuorovaikutusosaamistaan ja vuorovaikutustaitojaan tehokkaasti, on mahdollista että he pystyvät tunnistamaan potilaidensa ongelmia tarkemmin, potilaat ovat tyytyväisempiä saamaansa hoitoon ja ymmärtävät paremmin saamiaan hoito-ohjeita, potilaat sitoutuvat paremmin hoito-ohjeen noudattamiseen, potilaiden kokema huoli ja ahdistus vähenee ja lääkärin oma työhyvinvointi paranee (Maguire \& Pitceathly 2002). Viestintä- ja vuorovaikutusosaamisen kehittäminen on tärkeä osa lääkärin ammattitaidon kehittämistä ja siihen tulee panostaa myös lääkäreiden koulutuksessa. Poliitikon tehtävässä viestinnän ja vuorovaikutuksen päämäärät eivät välttämättä ole yhtä yksiselitteiset kuin lääkärin tehtävässä. Näin ollen ei myöskään ole mahdollista eritellä yhtä selkeästi viestintäja vuorovaikutusosaamisen yksittäisiä tuloksia tai erityisiä päämääriä, joihin viestinnällä kussakin tilanteessa tähdättäisiin. Juuri tämä tekeekin poliitikon viestintä- ja vuorovaikutusosaamisen tarkastelusta erityisen haastavan mutta samalla myös teoreettisesti ja tutkimuksellisesti kiintoisan ja hedelmällisen tarkastelukontekstin. Perinteisten, poliittista vakuuttamista tai vaikuttamista koskevien, luonteeltaan yksisuuntaisten taitokuvausten rinnalle olisi tärkeää luoda vuorovaikutus- ja suhdekeskeisiä lähestymistapoja päättäjien viestintä- ja vuorovaikutusosaamisen hahmottamiselle. Yksi 
tapa olisi siirtyä tarkastelemaan poliitikkojen kansalais- tai yhteiskuntasuhdetta kaksisuuntaisena yhteistyö- ja vuorovaikutussuhteena.

Viestintäosaamisen käsitteen sijasta päädyimme kuvailemaan lääkärin ja poliitikon ammatissa edellytettävää puheviestinnällistä osaamista erityisesti käsitteellä vuorovaikutusosaaminen. Tätä kautta pyrimme kiinnittämään huomiota suhteiden luomista ja ylläpitämistä korostavaan näkökulmaan niin lääkärin ammatissa kuin poliitikon tehtävässä. Tämän artikkelin kahta erilaista ammatillista näkökulmaa selkeimmin yhdistäväksi tekijäksi nousikin juuri vuorovaikutusosaamisen näkökulma, jossa korostuu viestinnän dialoginen luonne: vastavuoroisuus, kaksisuuntaisuus ja yhteistyöhakuisuus. Sekä poliitikon että lääkärin tehtävissä viestintä tapahtuu aina suhteessa toiseen, jolloin myös viestintäosaaminen on ihannetilanteessa luonteeltaan ennen kaikkea toisen osapuolen huomioivaa, tilanneherkkää toimintaa.

\section{KIRJALLISUUS}

Antikainen, A. 1998. Kasvatus, elämänkulku ja yhteiskunta. Porvoo: WSOY.

Aristoteles. 1997. Retoriikka. Runousoppi. (Suom. Paavo Hohti, Päivi Myllykoski \& Juha Sihvola). Tampere: Gaudeamus.

Barber, B. 1984. Strong democracy. Berkeley: University of California.

Brown, J. B., Steward, M. \& Ryan, B. L. 2003. Outcomes of patient-provider interaction. Teoksessa T. L. Thompson, A. M. Dorsey, K. I. Miller \& R. Parrot (toim.) Handbook of health communication. Mahwah: Lawrence Erlbaum, 141-161.

Bridge, K. \& Baxter, L. A. 1992. Blended friendships: friends as work associated. Western Journal of Communication, 56, 200-225.

Byrne, P. \& Long, B. E. L. 1976. Doctors talking to patients: a study of the verbal behaviours of doctors in the consultation. London: HMSO.

Cegala, D. J. \& Broz, S. L. 2003. Provider and patient communication skills training. Teoksessa T. L. Thompson, A. M. Dorsey, K. I. Miller \& R. Parrot (toim.) Handbook of health communication. Mahwah: Lawrence Erlbaum, 95-119.

Cegala, D. J., McGee, D. S. \& McNeilis, K. S. 1996. Components of patient' and doctors' perceptions of communication competence during a primary care medical interview. Health Communication 8, 1-27. 
Cegala, D. J. \& Waldron, V. R. 1992. A study of the relationship between communicative performance and conversation participants' thoughts. Communication Studies 43, 105-123.

Cooke, M. 2000. Five arguments for deliberative democracy. Political Studies 48 (2), 947-969.

Edelman, M. 1988. Constructing the political spectacle. Chicago: The University of Chicago Press.

Finstad, M. \& Isotalus, P. 2005. Näkökulmia poliitikon viestintäosaamiseen. Teoksessa T.-R. Välikoski, E. Kostiainen, E. Kyllönen \& L. Mikkola (toim.) Prologi. Puheviestinnän vuosikirja 2005. Jyväskylä: Prologos, 12-31.

Fishkin, J. 1995. The voice of the people. Public opinion and democracy. New Haven: Yale University Press.

Freidson, E. 1994. Professionalism reborn. Theory, prophecy and policy. Cambridge: Polity Press.

Gerlander, M. 2003. Jännitteet lääkärin ja potilaan välisessä viestintäsuhteessa. Jyväskylän yliopisto. Jyväskylä Studies in Humanities 3.

Gerlander, M. \& Takala, E. 2000. Viestinnän opetus interpersonaalisiin ammatteihin koulutettaessa. Teoksessa M. Valo (toim.) Nykytietoa puheviestinnän opetuksesta. Jyväskylän yliopiston viestintätieteiden laitoksen julkaisuja 20, 156-181.

Habermas, J. 1987. Järki ja kommunikaatio: tekstejä 1981-1985 / Jürgen Habermas; (valinnut ja suomentanut Jussi Kotkavirta.) Helsinki: Gaudeamus.

Herne, K. \& Setälä, M. 2005. Deliberatiivisen demokratian ihanteet ja kokeilut. Politiikka 47 (3), 175-188.

Isotalus, P. 2001. Presidential campaigning in Finland and Americanization. World Communication $30(2), 5-23$.

Jensen, J. 2003. Virtual democratic dialogue? Bringing together citizens and politicians. Information Polity 8 (1), 29-47.

Kaid, L. (toim.) 2004. Handbook of political communication research. Mahwah: Lawrence Erlbaum.

Kanerva, J. 1992. Politiikan teorian klassikoita. Helsinki: Yliopistopaino.

Kauppi, N. 2005. Median sekundatodellisuus: Pierre Bourdieun konstruktivismi viestinnän tutkimuksena. Teoksessa T. Mörä, I. Salovaara-Moring \& S. Valtonen (toim.) Mediatutkimuksen vaeltava teoria. Helsinki: Gaudeamus, 75-89.

Kostiainen, E. 2003. Viestintä ammattiosaamisen ulottuvuutena. Jyväskylän yliopisto. Jyväskylä Studies in Humanities 1.

Kreps, G. L. 1988. Relational communication in health care. Southern Speech Communication Journal 53, 344-359. 
Kurtz, S., Silverman, J. \& Draper, J. 2005. Teaching and learning communication skills in medicine. 2. painos. Oxford: Radcliffe.

Kyntäjä, T. 1989. Robert Michels. Teoksessa J. Kanerva (toim.) Politiikan teorian moderneja klassikkoja. Helsinki: Gaudeamus, 113-134.

Lappalainen, P. 2002. Poliittisen tyylin taito. Tampere: Vastapaino.

Lappalainen, P. 2006. Puolueohjelmien merkitys. Teoksessa J. Paastela \& H. Paloheimo (toim.) Suomen puolueiden periaateohjelmat: ohjelmat, niiden taustaa ja tarkastelua. Tampereen yliopisto: Politiikan tutkimuksen laitos, 259-275.

Lehtonen, J. 1994. Puhekasvatus ja sosiaaliset taidot. Teoksessa P. Isotalus (toim.) Puheesta ja vuorovaikutuksesta. Jyväskylä: Jyväskylän yliopiston viestintätieteiden laitos, 43-62.

Littlejohn, S. W. 2002. Theories of human communication. 7. painos. Belmont: Wadsworth.

Lääkärikysely. 2006. Helsinki: Suomen lääkäriliitto.

Maguire, P. \& Pitceathly, C. 2002. Key communication skills and how to acquire them. British Medical Journal 325, 697-700

Makoul, G. 2003. The interplay between education and research about patientprovider communication. Patient Education and Counselling 50, 79-84.

Mazzoleni, G. \& Schultz, W. 1999. Mediatization of politics. A challenge for democracy. Political Communication 16 (3), 247-261.

Michels, R. 1986. Puoluelaitos nykyajan demokratiassa. Juva: WSOY.

Ong, L. M. L., DeHaes, J. C. J. M., Hoos, A. M. \& Lammes, F. B. 1995. Doctor-patient communication: a review of the literature. Social Science \& Medicine 40, 903-918.

Paloheimo, H. (toim.) 2005. Vaalit ja demokratia Suomessa. Helsinki: WSOY.

Paloheimo, H. \& Wiberg, M. 1997. Politiikan perusteet. Helsinki: WSOY.

Palonen, K. 2002. Poliitikon arvostelukyvystä. Politiikka 44 (1), 64-69.

Parks, R. M. 1994. Communication competence and interpersonal control. Teoksessa M. L. Knapp \& G. R. Miller (toim.) Handbook of interpersonal communication. 2. painos. Beverly Hills: Sage, 589-618.

Pekonen, K. 1989. Max Weber. Teoksessa J. Kanerva (toim.) Politiikan teorian moderneja klassikkoja. Helsinki: Gaudeamus, 173-197.

Pesonen, N. 1980. Terveyden puolesta - sairautta vastaan. WSOY: Porvoo.

Peräkylä, A., Eskola, K. \& Sorjonen, M.-L. 2001. Lääkärin ja potilaan vuorovaikutus tarkastelun kohteena. Teoksessa M.-L. Sorjonen, E. Peräkylä \& K. Eskola (toim.) Keskusteluja lääkärin vastaanotolla. Tampere: Vastapaino, 7-26.

Pietilä, V. 2002. Verkkokeskusteluareenat - deliberatiivista julkisuuttako? Helsinki: Valtiotieteellinen yhdistys. 
Pyörälä, E. 2001. Keskusteluanalyyttisen vuorovaikutustutkimuksen soveltaminen lääkärikoulutuksessa. Teoksessa M.-L. Sorjonen, A. Peräkylä \& K. Eskola (toim.) Keskusteluja lääkärin vastaanotolla. Tampere: Vastapaino, 183-195.

Raevaara, L. 2000. Potilaan diagnoosiehdotukset lääkärin vastaanotolla. Keskustelunanalyyttinen tutkimus potilaan institutionaalisista tehtävistä. Helsinki: Suomalaisen Kirjallisuuden Seura.

Rauste-von Wright, M. \& von Wright, J. 1994. Oppiminen ja koulutus. Porvoo: WSOY.

Reunanen, E. 2003. Budjettijournalismi julkisena keskusteluna. Tampere: Tampereen yliopistopaino.

Rubin, R. B. 1990. Communication competence. Teoksessa G. M. Phillips \& J. T. Wood (toim.) Speech communication: essays to commemorate the 75th anniversary of the Speech Communication Association. Carbondale: Southern Illinois University Press, 94-129.

Ruusuvuori, J. 2000. Control in medical consultation. Practices of giving and receiving the reason for the visit in primary health care. Tampere: Tampereen yliopisto.

Ruusuvuori, J., Raevaara, L. \& Peräkylä, A. 2003. Potilas vaivansa tulkkina - ymmärtääkö lääkäri yskän? Suomen Lääkärilehti 58, 4219-4225.

Saarni, S. 2005. Lääkärin etiikka. 6. painos. Helsinki: Suomen Lääkäriliitto.

Setälä, M. 2003. Voiko poliitikkoihin luottaa? Politiikka 45 (4), 267-268.

Smith, R. C. \& Hoppe, R. B. 1991. The patient's story: integrating the patientand physician-centered approaches to interviewing. Annals of Internal Medicine 115, $470-477$.

Smith, R. C., Marshall-Dorsey, A. A., Osborn, G. G., Shebroe, V., Lyles, J. S., Stoffelmayr, B. E., Van Egeren, L. F., Mettler, J., Maduschke, K., Stanley, J. M. \& Gardiner, J. C. 2000 . Evidence-based guidelines for teaching patientcentered interviewing. Patient Education and Counceling 39, 27-36.

Spitzberg, B. H. \& Cupach, W. R. 1984. Interpersonal communication competence. Beverly Hills: Sage.

Spitzberg, B. H. \& Duran, R. L. 1994. Toward an ideological deconstruction of competence. Paper presented at International Communication Association Conference, Sydney, Australia, July 1994.

Street, R. L. Jr. 2003. Interpersonal communication skills in health care contexts. Teoksessa J. O. Greene \& B. R. Burleson (toim.) Handbook of communication and social interaction skills. Mahwah: Lawrence Erlbaum 909-933.

Thompson, T. L. 2003. Provider-patient interaction issues. Teoksessa T. L. Thompson, A. M. Dorsey, K. I. Miller \& R. Parrot (toim.) Handbook of health communication. Mahwah: Lawrence Erlbaum, 91-93. 
Vainiomäki, P. 1995. Kasvamassa lääkäriksi. Tutkimus juonneopetuksen suunnittelusta, toteutumisesta ja vaikutuksista Turun yliopiston lääketieteellisessä tiedekunnassa vuosina 1989-1993. Sarja C, 117. Turku: Turun yliopisto.

Valkonen, T. 2003. Puheviestintätaitojen arviointi. Näkökulmia lukiolaisten esiintymis- ja ryhmätaitoihin. Jyväskylän yliopisto. Jyväskylä Studies in Humanities 7.

Valo, M. Taidot puheviestinnän opetuksessa ja tutkimuksessa. Teoksessa M. Valo (toim.) Haasteita puheviestinnän opetukseen. Jyväskylän yliopisto. Viestintätieteiden laitoksen julkaisuja 14, 67-81.

Weber, M. 1964. Politics as vocation. New York: Oxford University Press.

Williams, S., Weinman, J. \& Dale, J. 1998. Doctor-patient communication and patient satisfaction: a review. Family Practice 15, 480-492. 